\title{
AN OVERVIEW OF THE HEALTH ECONOMIC \\ IMPLICATIONS OF ELECTIVE CAESAREAN SECTION
}

Stavros Petrou, $\mathrm{PhD}^{1}$ and Kamran Khan, $\mathrm{MSc}^{1}$

1. Warwick Clinical Trials Unit, Division of Health Sciences, Warwick Medical School, University of Warwick, Coventry CV4 7AL, UK.

\section{Contact for correspondence:}

Professor Stavros Petrou

Warwick Clinical Trials Unit

Division of Health Sciences

Warwick Medical School

University of Warwick

Coventry CV4 7AL

UK

Telephone: $\quad 00442476151124$

E-mail: $\quad$ s.petrou@warwick.ac.uk

Condensed running title: economic aspects of elective caesarean section

Word count:

3839 (main text) 


\section{Abstract}

The caesarean section rate has continued to increase in most industrialised countries, which raises a number of economic concerns. This paper provides an overview of the health economic implications of elective caesarean section. It provides a succinct summary of the health consequences associated with elective caesarean section for both the infant and the mother over the perinatal period and beyond. It highlights factors that complicate our understanding of the health consequences of elective caesarean section, including inconsistencies in definitions and coding of the procedure, the failure to adopt an intention to treat principle when drawing comparisons, and the widespread reliance on observational data. The paper then summarises the economic costs associated with elective caesarean section. Evidence is presented to suggest that planned caesarean section may be less costly than planned vaginal birth in some clinical contexts, for example where the singleton fetus lies in a breech position at term. In contrast, elective caesarean section (or caesarean section as a whole) appears to be more costly than vaginal delivery (either spontaneous or instrumented) in low risk or unselected populations. The paper proceeds with an overview of economic evaluations associated with elective caesarean section. All are currently based on decisionanalytic models. Evidence is presented to suggest that planned trial of labour (attempted vaginal birth) following a previous caesarean section appears to be a more cost-effective option than elective caesarean section, although its cost-effectiveness is dependent upon the probability of successful vaginal delivery. There is conflicting evidence on the costeffectiveness of maternal request caesareans when compared to trial of labour. The paucity of evidence on the value pregnant women, clinicians and other groups in society place on the option of elective caesarean section is highlighted. Techniques that might be used to elicit 
preferences for elective caesarean section and its attributes are outlined. The paper concludes with directions for future research in this area. 


\section{Key points for decision makers}

- $\quad$ Evidence is presented to suggest that planned caesarean section may be less costly than planned vaginal birth in some clinical contexts. In contrast, elective caesarean section (or caesarean section as a whole) appears to be more costly than vaginal delivery (either spontaneous or instrumented) in low risk or unselected populations.

- $\quad$ Planned trial of labour (attempted vaginal birth) following a previous caesarean section appears to be a more cost-effective option than elective caesarean section, although its cost-effectiveness is dependent upon the probability of successful vaginal delivery. There is conflicting evidence on the cost-effectiveness of maternal request caesareans when compared to trial of labour. 


\section{Introduction}

The term 'caesarean section' refers to the surgical procedure in which incisions are made in the mother's abdominal wall and uterus to deliver one or more babies, or, more rarely, to remove a dead fetus. Caesarean section has traditionally been divided into either elective or emergency procedures. Elective caesarean sections are planned and performed prior to labour; in contrast, emergency caesarean sections are unplanned and performed during labour, often in response to fetal compromise, failure to progress, antepartum haemorrhage or pregnancy-induced hypertension. The delineation of elective caesarean sections can be problematic with wide variations in what may be considered elective by both parturients and their health care providers. Clinical consensus is generally lacking on the medical and obstetric indications for elective caesarean sections, ${ }^{[1]}$ although recent guidelines from the National Institute of Health and Care Excellence (NICE) in England and Wales do provide evidence from systematic reviews or meta-analyses of randomised controlled trials to support elective caesarean sections for some indications, for example, singleton breech presentation at term where external cephalic version is contraindicated or has been unsuccessful. ${ }^{[2]}$ Similarly, the role of maternal request in determining whether an elective caesarean section is performed is often nebulous, and may be prompted by the suggestion of the physician or by a combination of decision-makers. Further, in several jurisdictions maternal request caesareans are often coded with other indications because of insurance coverage and liability concerns. ${ }^{[3]}$

The rate of caesarean section deliveries has increased markedly across the industrialised world in recent years. In the United States, for example, the percentage of all births that are caesarean deliveries increased substantially from 20.7\% in 1996 to an all-time high of 32.9\% in $2009,{ }^{[4]}$ with more than 1.3 million caesareans now performed annually. ${ }^{[5]}$ This has been accompanied by a simultaneous decrease in assisted vaginal birth rates. In England, the 
percentage of all births that are caesarean deliveries increased substantially from $9.0 \%$ in 1980 to an all-time high of $24.8 \%$ in 2009. ${ }^{[2]}$ Table 1 summarises recent caesarean section rates for member countries of the Organisation of Economic Co-operation and Development (OECD). A similar pattern has been observed in non-OECD member countries. Surveys of maternal and perinatal health funded by the World Health Organisation revealed a median rate of caesarean delivery of 33\% across eight randomly selected countries in Latin America, with 55\% performed in private hospitals. ${ }^{[6]}$ Further, primary caesarean rates have increased markedly; women who have a primary caesarean section have a greater than $90 \%$ chance of having a repeat caesarean section, further increasing overall caesarean rates in the future. ${ }^{[7]}$ National estimates of the elective primary caesarean delivery rate have generally shown rising trends across jurisdictions. ${ }^{[1,4]}$

A number of factors have contributed to the increasing rates of caesarean delivery. These include improved surgical and anaesthetic techniques, reduced risk of post-operative complications, demographic and nutritional factors, providers' and patients' perception of the safety of the procedure, and changes in health systems (with a gradual move away from outof-hospital settings and low technology midwifery and obstetrics in many jurisdictions). ${ }^{[4,6]}$ The contribution of maternal requests for non-medical reasons to increasing rates of elective caesarean delivery is difficult to quantify. The popular notion of significant numbers of women being "too posh to push" is generally not borne out by the empirical evidence. A recent critical review of the literature found that the phenomenon of true maternal request caesareans remains relatively rare. ${ }^{[8]}$ Quantifying the contribution of economic incentives to increasing rates of caesarean delivery is also far from straightforward. A small number of econometric studies have suggested that physicians' financial incentives and concerns about bearing the personal risk of malpractice may play some role. ${ }^{[9,10]}$ 
The economic consequences of increasing caesarean delivery rates are potentially of great relevance to decision-makers. Drawing upon evidence identified through searches of PubMed, EMBASE, CINAHL, the Cochrane Library, Web of Knowledge and Google Scholar, and studies published since 2000 (search strategy presented in Appendix 1), this article provides an overview of economic issues surrounding elective caesarean section. It highlights gaps in our current knowledge of the topic and identifies requirements for further research in this area. We begin with a brief overview of the evidence on the health consequences of elective caesarean section.

\section{Health Consequences Associated with Elective Caesarean Section}

Assessments of the health consequences of elective caesarean section are complicated by several factors. First, published studies have not defined elective caesarean section in a consistent way, and often use indirect evidence from proxies, such as planned caesareans (which may or may not include women or foetuses with defined medical indications), 'unlaboured' caesareans, or caesareans performed without a defined medical indication. Second, the majority of studies published to date have compared health consequences by actual mode of delivery, not planned mode of delivery. Comparisons should ideally be based on the intention to treat principle and compare planned modes of delivery among women with a defined risk profile. Third, existing studies are not always based on ideal clinical practices for alternative modes of delivery, so the balance of risks and benefits may alter in an improved practice environment, or at least one with an alternative configuration of trained medical and nursing staff that adheres to evidence-based clinical protocols. Fourth, and perhaps most importantly, the evidence is largely drawn from observational sources and, therefore, prone to the selection biases common to non-randomised studies more broadly. 
One large multi-centre randomised controlled trial of planned caesarean section versus planned vaginal birth for breech presentation revealed that rates of perinatal mortality, neonatal mortality, and serious neonatal morbidity were significantly lower in the planned caesarean group. ${ }^{[11]}$ However, this trial is of questionable relevance to elective caesarean section as some trial participants were in labour before presentation. Furthermore, the results of trials comparing planned caesarean section performed for medical indications with alternative planned modes of delivery are not applicable to contexts without medical indications, because caesarean mortality and morbidity is confounded by pre-existing obstetric or general medical conditions. ${ }^{[12]}$

Despite these caveats, a number of studies have examined the risks and benefits of elective caesarean section versus vaginal delivery for the infant. A recent review article concluded that elective caesarean section is associated with increased risk for neonatal respiratory morbidity and fetal laceration and potentially decreased risk for brachial plexus injury, neonatal sepsis, intracranial haemorrhage, intrapartum asphyxia, and neonatal encephalopathy, compared with vaginal delivery. ${ }^{[13]}$ A recent population-based study from the United States that used linked birth and death certificates to analyse data for women without medical indications revealed an odds ratio for neonatal mortality for primary caesarean delivery of 2.02 (95\% CI: $1.60-2.55)$ compared with vaginal delivery. ${ }^{[14]}$ However, some investigators have noted that this may be counterbalanced by preventive benefits in terms of antepartum stillbirths, particularly at 39 weeks gestation and beyond. ${ }^{[15,16]}$

The risks and benefits of elective caesarean section for the mother have been summarised in a number of review articles. ${ }^{[3,17,18]}$ Limited observational evidence suggests no difference in maternal mortality between planned caesarean delivery and planned vaginal delivery. ${ }^{[3]}$ One systematic review, which also graded the quality of evidence, revealed that planned caesarean delivery is associated with a lower risk of haemorrhage and blood transfusion, no 
difference in emergency hysterectomy, postpartum pain, postpartum depression, and duration of breastfeeding, and weak evidence of a higher risk of anaesthetic complications and maternal infection, in comparison with planned vaginal delivery. ${ }^{[3]}$ The same review revealed that planned caesarean delivery is associated with a lower risk of maternal infection and surgical complications, in comparison with unplanned 'emergency' or 'laboured' caesarean deliveries. $^{[3]}$

The consequences of elective caesarean for maternal health have also been measured over the longer term. Of particular note is evidence from a large body of literature to suggest that rates of stress urinary incontinence following elective caesarean section are either lower or no different to those following vaginal delivery. ${ }^{[3]}$ Weak evidence suggests a lower risk of anal incontinence following elective caesarean section in comparison to either instrumental vaginal deliveries or unplanned ‘emergency' or 'laboured' caesarean deliveries. ${ }^{[3]}$ Although one study estimated an increased risk of subsequent stillbirth associated with all caesarean deliveries, it did not control for medical indications. ${ }^{[19]}$ Consequently, the consequences of elective caesarean section for subsequent reproductive health remain relatively unexplored.

\section{Economic Costs Associated with Elective Caesarean Section}

In this section, we focus on evidence on the economic costs associated with elective caesarean section, drawing largely from 15 studies identified by the literature searches and published since 2000. ${ }^{[20-34]}$ The summary methods of each of these studies are reported in Table 2. This includes an overall assessment of study quality based on 12 relevant reporting items included in the recently published Consolidated Health Economic Evaluation Reporting Standards (CHEERS) statement. ${ }^{[35]}$ The results of each of these studies are summarised in Appendix 2. 
The studies varied in their comparison groups. Five studies compared elective caesarean section (or, where this was not available, caesarean section as a whole) with alternative modes of delivery in selected clinical populations, either following a previous caesarean section $^{[23,26,29]}$ or following a singleton breech presentation. ${ }^{[28,32]}$ Overall mean cost estimates were higher for the mother, infant and mother-infant dyad when planned elective caesarean section was compared with planned trial of labour (attempted vaginal birth) following a previous caesarean section. However, there is evidence to suggest that failed vaginal birth after caesarean accounts for the most expensive total birth experience in this clinical context, largely driven by the recourse to operative delivery and increased rates of infant admissions to neonatal units and subsequent oxygen requirements. ${ }^{[26,29]}$ Evidence from the Term Breech trial suggests that planned caesarean is less costly, on average, than planned vaginal birth for the singleton fetus in a breech presentation at term (Can\$7,165 versus \$8,042; 2002 prices). ${ }^{[32]}$ Although the planned caesarean group incurred higher costs, on average, for pre-labour caesareans, which included procedure fees as well as the costs associated with time in the operating room, the postnatal ward and the normal nursery, women in the planned vaginal birth group spent more time, on average, in the labour and delivery suite, and their infants required more care in neonatal intensive and intermediate care units.

The remaining ten studies compared elective caesarean section (or caesarean section as a whole) with alternative modes of delivery in low risk pregnancies ${ }^{[20,21,25,27]}$ or unselected populations. ${ }^{[22,24,30,31,33,34]}$ Here, a consistent pattern emerged with all studies reporting higher mean costs of initial hospital stay for elective caesarean section (or caesarean section as a whole) compared to vaginal delivery (either spontaneous or instrumented). Methodological differences between studies restrict the value of pooling costs across health systems, jurisdictions and time periods. Nevertheless, the mean cost of the initial hospital stay 
following elective caesarean section (or caesarean section as a whole) varied between 1.1 and 4.1 times that following vaginal delivery (either spontaneous or instrumented) (Appendix 2). ${ }^{[20,31]}$ Previous reviews have highlighted the importance of differences in medical and nursing staff costs, equipment and consumables, and labour and delivery suite and operating theatre overheads between elective caesarean section and vaginal delivery. ${ }^{[36]}$ Another factor driving the difference in mean cost of the initial hospitalisation is the length of postnatal stay. Declercq and colleagues analysed routine data extracted from birth certificates and birthrelated hospital discharge records from Massachusetts, United States, and estimated a mean postnatal stay of 4.3 days for planned primary caesarean births compared to 2.4 days for planned vaginal births. ${ }^{[25]}$ Similarly, Petrou and Glazener analysed data from a random sample of 1242 women receiving postnatal care in the Grampian Region of Scotland during the period June 1990 to May 1991. They estimated a mean postnatal stay of 7.1 days for caesarean births as a whole compared to 4.4 days for vaginal births. ${ }^{[33]}$

Three further points are worthy of note. First, the limited time horizon of all reviewed studies is likely to underestimate the economic costs associated with each mode of delivery and, potentially, the cost differences between elective caesarean caesarean section and alternative modes of delivery. The Grampian study by Petrou and Glazener revealed that hospital readmission costs during the first two moths postpartum were significantly higher following a caesarean section (UK£3200 versus $£ 1698$ following a spontaneous vaginal delivery; 1999-2000 prices)). ${ }^{[33]}$ Furthermore, a Taiwanese population-based study revealed that hospital outpatient costs were significantly higher following elective caesarean section, compared to vaginal delivery, during the first six months postpartum. ${ }^{[37]}$ Second, and related, almost all reviewed studies are underpowered to detect rare adverse sequelae. There is a suggestion of increased occurrence of asthma, food allergy and obesity extending into adulthood, following caesarean section. ${ }^{[38]}$ The life-long costs associated with these health 
sequelae might be considerable and may outweigh short-term concerns. Third, all reviewed studies ignore direct non-medical costs and indirect costs associated with alternative modes of delivery. There may be an assumption that women are economically unproductive for a period following childbirth, thus wider economic costs are likely to be the same whatever the mode of delivery. This narrow viewpoint ignores additional care and support of women at home often provided by relatives and friends during the postnatal period. This may constitute both direct costs, for example, in terms of travel, and indirect costs if they take additional time off work.

\section{Economic Evaluations Associated with Elective Caesarean Section}

In this section, we focus on evidence on economic evaluations associated with elective caesarean section, drawing largely from 12 studies identified by the literature searches and published since 2000. ${ }^{[2,39-49]}$ The summary methods of each of these studies are reported in Table 3. This includes an overall assessment of study quality based on all reporting items included in the recently published Consolidated Health Economic Evaluation Reporting Standards (CHEERS) statement. ${ }^{[35]}$. The results of each of these studies are summarised in Appendix 3.

The most common comparator for elective caesarean section was planned trial of labour (attempted vaginal birth) following a previous caesarean section. ${ }^{[40,42,43]}$ A consistent pattern is reported with trial of labour clearly emerging as the most cost-effective planned mode of delivery following a previous caesarean section. Nevertheless, its cost-effectiveness is dependent upon the probability of successful vaginal delivery. Chung and colleagues concluded that a success rate of at least $74 \%$ was required for trial of labour to achieve cost- 
effectiveness, ${ }^{[40]}$ whilst Fawsitt and colleagues found that trial of labour remained costeffective with success rates as low as $67 \% .^{[42]}$

Two studies evaluated the cost-effectiveness of maternal request caesareans. ${ }^{[2,49]} \mathrm{Xu}$ and colleagues used a Monte Carlo simulation decision model to compare the cost-effectiveness of maternal request caesareans with trial of labour in primigravid women without a medical or obstetric indication for caesarean section in the United States. ${ }^{[49]}$ The authors report a probability of cost-effectiveness of $82 \%$ for maternal request caesareans at a societal costeffectiveness threshold of US\$50,000 for an additional quality-adjusted life year (QALY). This contrasts with the results of a cost-effectiveness model developed on behalf of NICE in England and Wales, ${ }^{[2]}$ which found that trial of labour dominated maternal request caesareans with a probability of cost-effectiveness of $100 \%$ across cost-effectiveness thresholds. The divergent findings are likely to be explained, at least in part, by two factors. First, although the decision-analytic model developed by Xu and colleagues was informed by the published literature, the evidence was not clearly reviewed and extracted in a systematic manner. Second, and perhaps more pertinently, much of the evidence used to populate their model was not based on planned mode of delivery.

Other economic evaluations have demonstrated that elective caesarean section represents a cost-effective mode of delivery in selected clinical contexts. This includes in HIV infected women where there is an interest in the prevention of mother-to-child transmission of the virus. ${ }^{[39,44,46]}$ Recent evidence suggests that the risk of HIV transmission is the same for a caesarean section and a vaginal birth in women on highly active anti-retroviral therapy with a viral load of less than 400 copies per ml or any anti-retroviral therapy with a viral load of less than 50 copies per ml, and consequently that elective caesareans should not be offered to these subgroups. ${ }^{[2]}$ In the context of women who are infected with the hepatitis $C$ virus, the cost-effectiveness of elective caesarean section remains highly dependent upon the mother- 
to-child transmission rate. ${ }^{[47]}$ Limited observational evidence suggests that there is no difference in risk of vertical transmission by mode of delivery. ${ }^{[2]}$ Therefore, policy makers understandably remain reluctant to recommend elective caesareans for these women. However, in the subgroup of women co-infected with HIV, clinical and cost-effectiveness evidence both support the offer of elective caesareans, driven by reduction in mother-to-child transmission of both the hepatitis C virus and HIV. ${ }^{[2,48]}$

\section{Preferences for Elective Caesarean Section}

Regardless of the evidence surrounding the economic cost and cost-effectiveness of elective caesarean section in various contexts, some women may still request this mode of delivery in the absence of any clinical reason. Underpinning these requests lay a range of personal factors, including fear of birth, perceived inequality and inadequacy of care, and family obligations, such as the need for a shorter recovery period so that women can care for other children at home. ${ }^{[8,50,51]}$ The cultural, institutional and professional settings in which decisions about mode of delivery are made may also play an important role. ${ }^{[8]}$

Relatively small surveys of obstetricians’ preferences have suggested that a significant minority of obstetricians would choose a delivery by elective caesarean section for themselves or their partner. ${ }^{[52-54]}$ It is hardly surprising, therefore, that similar views should prevail among some women of child-bearing age. We are not aware of any studies conducted by health economists that have attempted to quantify the relative contribution of health outcomes, non-health outcomes and process attributes to women's or obstetricians' decisionmaking about elective caesarean section. One study has estimated changes in willingness to pay, measured at pregnancy and postpartum, for maternity services in a fee-paying low income country setting. ${ }^{[55]}$ However, this study didn't disentangle the relative importance of 
factors underpinning those valuations; neither did it focus specifically on the option of elective caesarean section.

Clearly, preference elicitation techniques developed or used by economists, such as contingent valuation or discrete choice experiments, should have a role in future research in this area. Regardless of the preferences of women or clinicians for attributes of elective caesarean section and alternative modes of delivery, the normative question of whether nonhealth outcomes and process attributes should influence the way intrapartum care is organised remains. Regulatory and reimbursement decisions in many jurisdictions are largely driven by concerns around clinical and, ultimately, cost-effectiveness. Convincing decision-makers about the need to incorporate factors of potential broader value remains a challenge to health economists working in the area.

\section{Future Research Directions}

The caesarean section rate has continued to increase in most industrialised countries. Routine data in many countries also provide evidence of increasing rates of elective caesarean section. This paper provides an overview of the health consequences associated with elective caesarean section for both the infant and the mother over the perinatal period and beyond. It highlights factors that complicate our understanding of the health consequences of elective caesarean section, including inconsistencies in definitions and coding of the procedure, the failure to adopt an intention to treat principle when drawing comparisons, and the widespread reliance on observational data. There are several health consequences of elective caesarean section we still know little about, including the long-term neurological sequelae for the infant and the future reproductive health of the mother. There is clearly a need for consistent coding of elective caesareans across routine data collection systems. Linkage across routine health 
data collection systems, both on a cross-sectional and longitudinal basis, should increase our understanding of the health consequences of this and alternative modes of delivery. Given the reliance on individual-level observational data, approaches such as propensity score analysis and matching techniques will increasingly come into view for handling selection biases when drawing these comparisons.

The paper provides an overview of the economic costs associated with elective caesarean section. Evidence is presented to suggest that planned caesarean section may be less costly than planned vaginal birth in some clinical contexts, for example where the singleton fetus lies in a breech position at term. ${ }^{[32]}$ Even here, however, the inclusion of some women in labour at the start of the analyses conducted muddies the generalisations that can be made about elective caesareans per se. A more consistent pattern of evidence is presented when elective caesarean section (or caesarean section as a whole) is compared to vaginal delivery (either spontaneous or instrumented) in low risk or unselected populations. Elective caesareans (or caesareans as a whole) are consistently more expensive than vaginal deliveries. Nevertheless, the viewpoint of almost all published studies in this area is limited to that of the health care provider, and the time horizon generally short term, rarely extending beyond the postnatal period. Ideally, the economic costs associated with elective caesarean section and alternative modes of delivery should be estimated from data gathered in largescale longitudinal studies as they become available. An early example of this is provided by the economic analyses based on the Grampian cohort study. ${ }^{[33]}$

The paper also provides an overview of economic evaluations associated with elective caesarean section. There are several aspects of the management of elective caesareans for which cost-effectiveness evidence is lacking, for example the appropriate timing of antibiotic prophylaxis to reduce post-operative maternal infective morbidity rates. All existing economic evaluations of aspects of elective caesarean section are based on decision-analytic 
models. Although modelling-based economic evaluations are inevitable in several circumstances, trial-based economic evaluations offer some distinct advantages. Perhaps most importantly, access to individual patient data permits a wide range of statistical and econometric techniques, for example to examine the relation between events of interest and health-related quality of life, or to explore sub-group differences. ${ }^{[56]}$ Randomised controlled trials that involve the option of elective caesarean section are likely to be required in several clinical contexts, for example, preterm breech, a breech presentation that is diagnosed in the second stage of labour, delivery of twin and triplet pregnancies, and delivery of 'small for gestational age' babies. ${ }^{[2]}$ These trials should ideally incorporate prospective economic evaluations and measure and value both costs and health consequences over the long-term. Such evidence is required to inform the efficient allocation of scarce resources in this area.

Finally, the paper highlights the paucity of evidence on the value pregnant women, clinicians and other groups in society place on the option of elective caesarean section. We are not aware of any preference elicitation studies in this area. Particular attention should be paid to ensuring the attributes valued in these studies reflect women's views of elective caesarean section. Synthesising these preferences within a broader economic evaluation framework will be a challenge, particularly if they reflect concerns around non-health outcomes or process attributes, such as avoiding labour pain or perceptions of the quality of care provided.

\section{Conclusions}

This paper provides an overview of the health economic implications of elective caesarean section. It provides a succinct summary of the evidence surrounding the health consequences, 
economic costs, cost-effectiveness and preferences associated with elective caesarean section. Directions for future research of relevance to health economists are outlined. 


\section{Acknowledgements}

The Warwick Clinical Trials Unit benefited from facilities funded through the Birmingham Science City Translational Medicine Clinical Research and Infrastructure Trials Platform, with support from Advantage West Midlands. The funding bodies had no influence on the writing of this paper or the decision to submit the paper for publication. The views contained in the paper are those of the authors and not necessarily of the funding bodies.

\section{Conflicts of interest}

None

\section{Author contributions}

SP designed this review article, synthesised and interpreted the relevant information, and wrote the article. KK conducted the literature reviews and extracted relevant data from selected studies. SP acts as the guarantor for the overall content. 


\section{References}

1. Meikle SF, Steiner CA, Zhang J, Lawrence WL. A national estimate of the elective primary cesarean delivery rate. Obstet Gynecol 2005; 105 (4): 751-6

2. National Collaborating Centre for Women and Childrens Health (NCCWCH). Caesarean Section. London: Royal College of Obstetricians and Gynaecologists, 2011

3. Visco AG, Viswanathan M, Lohr KN, Wechter ME, Gartlehner G, Wu JM et al. Cesarean delivery on maternal request: maternal and neonatal outcomes. Obstet Gynecol 2006; 108 (6): 1517-29. doi:10.1097/01.AOG.0000241092.79282.87.

4. Niino Y. The increasing cesarean rate globally and what we can do about it. Biosci Trends 2011; 5 (4): 139-50

5. MacDorman MF, Menacker F, Declercq E. Cesarean birth in the United States: epidemiology, trends, and outcomes. Clin Perinatol 2008; 35 (2): 293-307

6. Villar J, Valladares E, Wojdyla D, Zavaleta N, Carroli G, Velazco A et al. Caesarean delivery rates and pregnancy outcomes: the 2005 WHO global survey on maternal and perinatal health in Latin America. Lancet 2006; 367 (9525): 1819-29

7. Ramachandrappa A, Jain L. Elective cesarean section: its impact on neonatal respiratory outcome. Clin Perinatol 2008; 35 (2): 373-93

8. McCourt C, Weaver J, Statham H, Beake S, Gamble J, Creedy DK. Elective cesarean section and decision making: a critical review of the literature. Birth 2007; 34 (1): 65-79

9. Gruber J, Owings M. Physician financial incentives and cesarean section delivery. Rand J Econ 1996; 27 (1): 99-123

10. Eckerlund I, Gerdtham UG. Econometric analysis of variation in cesarean section rates. A cross-sectional study of 59 obstetrical departments in Sweden. Int J Technol Assess 1998; 14 (4): 774-87 
11. Hannah ME, Hannah WJ, Hewson SA, Hodnett ED, Saigal S, Willan AR. Planned caesarean section versus planned vaginal birth for breech presentation at term: a randomised multicentre trial. Term Breech Trial Collaborative Group. Lancet 2000; 356 (9239): 1375-83

12. Lavender T, Hofmeyr GJ, Neilson JP, Kingdon C, Gyte GM. Caesarean section for nonmedical reasons at term. Cochrane Database Syst Rev. 2012; 3

13. Signore C, Klebanoff M. Neonatal morbidity and mortality after elective cesarean delivery. Clin Perinatol 2008; 35 (2): 361-71

14. MacDorman MF, Declercq E, Menacker F, Malloy MH. Infant and neonatal mortality for primary cesarean and vaginal births to women with "no indicated risk," United States, 1998-2001 birth cohorts. Birth 2006; 33 (3): 175-82 doi:10.1111/j.1523536X.2006.00102.X.

15. Signore C, Hemachandra A, Klebanoff M. Neonatal mortality and morbidity after elective cesarean delivery versus routine expectant management: a decision analysis. Semin Perinatol 2006; 30 (5): 288-95 doi:10.1053/j.semperi.2006.07.010.

16. Hankins GD, Clark SM, Munn MB. Cesarean section on request at 39 weeks: impact on shoulder dystocia, fetal trauma, neonatal encephalopathy, and intrauterine fetal demise. Semin Perinatol 2006; 30 (5): 276-87 doi:10.1053/j.semperi.2006.07.009.

17. Lee YM, D'Alton ME. Cesarean delivery on maternal request: maternal and neonatal complications. Curr Opin Obstet Gyn 2008; 20 (6): 597-601

18. Silver RM. Delivery after previous cesarean: long-term maternal outcomes. Semin Perinatol 2010; 34 (4): 258-66 doi:10.1053/j.semperi.2010.03.006.

19. Smith GC, Pell JP, Dobbie R. Caesarean section and risk of unexplained stillbirth in subsequent pregnancy. Lancet 2003; 362 (9398): 1779-84 
20. Allen VM, O'Connell CM, Farrell SA, Baskett TF. Economic implications of method of delivery. Am J Obstet Gynecol 2005; 193 (1): 192-7

21. Allen VM, O’Connell CM, Baskett TF. Cumulative economic implications of initial method of delivery. Obstet Gynecol 2006; 108 (3, Part 1): 549-55

22. Bost BW. Cesarean delivery on demand: what will it cost? Am J Obstetr Gynecol 2003; 188 (6): 1418-23

23. Clark SL, Scott JR, Porter TF, Schlappy DA, McClellan V, Burton DA. Is vaginal birth after cesarean less expensive than repeat cesarean delivery? Am J Obstet Gynecol 2000; 182 (3): 599-602

24. Comas M, Català L, Sala M, Payà A, Sala A, Del Amo E et al. Descriptive analysis of childbirth healthcare costs in an area with high levels of immigration in Spain. BMC Health Serv Res 2011; 11 (1): 77

25. Declercq E, Barger M, Cabral HJ, Evans SR, Kotelchuck M, Simon C et al. Maternal outcomes associated with planned primary cesarean births compared with planned vaginal births. Obstet Gynecol 2007; 109 (3): 669-77

26. DiMaio H, Edwards RK, Euliano TY, Treloar RW, Cruz AC. Vaginal birth after cesarean delivery: an historic cohort cost analysis. Ame J Obstet Gynecol 2002; 186 (5): 890-2

27. Heer I, Kahlert S, Rummel S, Kümper C, Jonat W, Strauss A. Hospital treatment-is it affordable? A structured cost analysis of vaginal deliveries and planned caesarean sections. Eur J Med Res 2009; 14 (11): 502

28. James M, Hunt K, Burr R, Johanson R. A decision analytical cost analysis of offering ECV in a UK district general hospital. BMC Health Serv Res 2001; 1 (1): 6

29. Kamath BD, Todd JK, Glazner JE, Lezotte D, Lynch AM. Neonatal outcomes after elective cesarean delivery. Obstet Gynecol 2009; 113 (6): 1231-8 
30. Kazandjian VA, Chaulk CP, Ogunbo S, Wicker K. Does a Cesarean section delivery always cost more than a vaginal delivery? J Eval Clin Pract 2007; 13 (1): 16-20

31. Khan A, Zaman S. Costs of vaginal delivery and Caesarean section at a tertiary level public hospital in Islamabad, Pakistan. BMC Pregnancy Childbirth 2010; 10 (1): 2

32. Palencia R, Gafni A, Hannah ME, Ross S, Willan AR, Hewson S et al. The costs of planned cesarean versus planned vaginal birth in the Term Breech Trial. CMAJ 2006; 174 (8): 1109-13 doi:10.1503/cmaj.050796.

33. Petrou S, Glazener C. The economic costs of alternative modes of delivery during the first two months postpartum: results from a Scottish observational study. BJOG Int J Obstet Gy 2002; 109 (2): 214-7

34. Sarowar M, Medin E, Gazi R, Koehlmoos T, Rehnberg C, Saifi R et al. Calculation of Costs of Pregnancy-and Puerperium-related Care: Experience from a Hospital in a Lowincome Country. J Health Popul Nutr 2010; 28 (3): 264

35. Husereau D, Drummond M, Petrou S, Carswell C, Moher D, Greenberg D et al. Consolidated Health Economic Evaluation Reporting Standards (CHEERS) statement. BMJ. 2013; 346: f1049 doi:10.1136/bmj.f1049.

36. Henderson J, McCandlish R, Kumiega L, Petrou S. Systematic review of economic aspects of alternative modes of delivery. BJOG Int J Obstet Gy 2001; 108 (2): 149-57 doi:10.1111/j.1471-0528.2001.00044.x.

37. Liu TC, Chen CS, Lin HC. Does elective caesarean section increase utilization of postpartum maternal medical care? Med Care 2008; 46 (4): 440-3 doi:10.1097/MLR.0b013e31816493e9.

38. Steer PJ, Modi N. Elective caesarean sections--risks to the infant. Lancet 2009; 374 (9691): 675-6 doi:10.1016/S0140-6736(09)61544-0. 
39. Chen KT, Sell RL, Tuomala RE. Cost-Effectiveness of Elective Cesarean Delivery in Human Immunodeficiency Virus-Infected Women. Obstet Gynecol 2001; 97 (2): 161-8

40. Chung A, Macario A, El-Sayed YY, Riley ET, Duncan B, Druzin ML. Costeffectiveness of a trial of labor after previous cesarean. Obstet Gynecol 2001; 97 (6): $932-41$

41. Culligan PJ, Myers JA, Goldberg RP, Blackwell L, Gohmann SF, Abell TD. Elective cesarean section to prevent anal incontinence and brachial plexus injuries associated with macrosomia—a decision analysis. Int Urogynecol J 2005; 16 (1): 19-28

42. Fawsitt CG, Bourke J, Greene RA, Everard CM, Murphy A, Lutomski JE. At What Price? A Cost-Effectiveness Analysis Comparing Trial of Labour after Previous Caesarean versus Elective Repeat Caesarean Delivery. PloS One 2013; 8 (3): e58577

43. Grobman WA, Peaceman AM, Socol ML. Cost-effectiveness of elective cesarean delivery after one prior low transverse cesarean. Obstet Gynecol 2000; 95 (5): 745-51

44. Halpern MT, Read JS, Ganoczy DA, Harris DR. Cost-effectiveness of cesarean section delivery to prevent mother-to-child transmission of HIV-1. AIDS 2000; 14 (6): 691-700

45. Herbst MA. Treatment of suspected fetal macrosomia: a cost-effectiveness analysis. Am J Obstet Gynecol 2005; 193 (3 Pt 2): 1035

46. Mrus JM, Goldie SJ, Weinstein MC, Tsevat J. The cost-effectiveness of elective Cesarean delivery for HIV-infected women with detectable HIV RNA during pregnancy. AIDS 2000; 14 (16): 2543-52

47. Plunkett BA, Grobman WA. Elective cesarean delivery to prevent perinatal transmission of hepatitis C virus: a cost-effectiveness analysis. Am J Obstet Gynecol 2004; 191 (3): 998-1003 
48. Schackman BR, Oneda K, Goldie SJ. The cost-effectiveness of elective Cesarean delivery to prevent hepatitis C transmission in HIV-coinfected women. AIDS 2004; 18 (13): $1827-34$

49. Xu X, Ivy JS, Patel DA, Patel SN, Smith DG, Ransom SB et al. Pelvic floor consequences of cesarean delivery on maternal request in women with a single birth: a cost-effectiveness analysis. J Women's Health 2010; 19 (1): 147-60

50. Eden KB, Hashima JN, Osterweil P, Nygren P, Guise JM. Childbirth preferences after cesarean birth: a review of the evidence. Birth 2004; 31 (1): 49-60

51. Mazzoni A, Althabe F, Liu NH, Bonotti AM, Gibbons L, Sánchez AJ et al. Women’s preference for caesarean section: a systematic review and meta-analysis of observational studies. BJOG Int J Obstet Gy 2011; 118 (4): 391-9 doi:10.1111/j.14710528.2010.02793.x.

52. Paterson-Brown S. Should doctors perform an elective caesarean section on request? Yes, as long as the woman is fully informed. BMJ 1998; 317 (7156): 462-3

53. Cotzias CS, Paterson-Brown S, Fisk NM. Obstetricians say yes to maternal request for elective caesarean section: a survey of current opinion. Eur J Obstet Gyn R B 2001; 97 (1): $15-6$

54. Klein MC, Liston R, Fraser WD, Baradaran N, Hearps SJ, Tomkinson J et al. Attitudes of the new generation of Canadian obstetricians: how do they differ from their predecessors? Birth 2011; 38 (2): 129-39 doi:10.1111/j.1523-536X.2010.00462.x.

55. Gartoulla P, Liabsuetrakul T, Pradhan N. Change in willingness to pay for normal delivery and caesarean section during pregnancy and after delivery in Kathmandu. Trop Med Int Health 2010; 15 (10): 1227-34 doi:10.1111/j.1365-3156.2010.02596.x.

56. Petrou S, Gray A. Economic evaluation alongside randomised controlled trials: design, conduct, analysis, and reporting. BMJ 2011; 342: d1548 doi:10.1136/bmj.d1548. 
57. OECD Health Data. Health care resources: OECD Health Statistics. Paris, France:

Organisation for Economic Co-operation and Development (OECD), 2012.

(http://www.oecd-ilibrary.org/social-issues-migration-health/data/oecd-health-

statistics_health-data-en) 
Table 1: Caesarean section rates from 1900 to 2010 within 31 developed countries

\begin{tabular}{|c|c|c|c|c|c|c|c|c|c|c|c|c|}
\hline & 1990 & 2000 & 2001 & 2002 & 2003 & 2004 & 2005 & 2006 & 2007 & 2008 & 2009 & 2010 \\
\hline Australia & 17.5 & 23.1 & 25.1 & 26.8 & 28.2 & 29.1 & 30.0 & 30.3 & 30.6 & 30.8 & 31.2 & - \\
\hline Austria & - & 16.8 & 18.0 & 19.8 & 20.7 & 22.8 & 23.8 & 25.1 & 26.5 & 27.1 & 28.2 & 28.2 \\
\hline Belgium & 10.4 & 16.3 & 16.3 & 17.4 & 17.6 & 17.8 & - & - & 17.3 & 19.7 & - & - \\
\hline Canada & 19.1 & 20.9 & 22.2 & 23.4 & 24.8 & 25.3 & 26.2 & 26.3 & 26.6 & 26.4 & 26.2 & - \\
\hline Czech Republic & 7.6 & 12.9 & 13.3 & 14.1 & 15.3 & 16.0 & 17.1 & 18.4 & 19.6 & 20.5 & 21.2 & 22.5 \\
\hline Denmark & 12.6 & 12.9 & 13.6 & 16.0 & 15.3 & 16.5 & 17.3 & 17.4 & 17.7 & 16.6 & 20.6 & 21.1 \\
\hline Estonia & 6.3 & 14.6 & 15.5 & 15.0 & 16.4 & 17.2 & 18.9 & 19.0 & 20.0 & 20.0 & 20.7 & 20.4 \\
\hline Finland & 13.5 & 15.8 & 16.5 & 16.4 & 16.2 & 16.4 & 16.3 & 16.1 & 16.3 & 16.5 & 15.7 & 16.1 \\
\hline France & 13.9 & 17.2 & 17.8 & 18.5 & 18.6 & 18.7 & 19.1 & 19.5 & 19.9 & 19.9 & 20.0 & 20.3 \\
\hline Germany & 15.7 & 20.9 & 22.0 & 23.7 & 24.8 & 26.0 & 26.7 & 27.8 & 28.5 & 29.4 & 30.3 & 31.4 \\
\hline Hungary & - & - & - & - & - & 27.1 & 29.2 & 29.3 & 30.3 & 31.44 & 32.52 & - \\
\hline Iceland & 11.8 & 17.7 & 16.8 & 17.4 & 17.9 & 16.4 & 15.6 & 17.2 & 16.9 & 16.1 & 15.8 & - \\
\hline Ireland & 10.5 & 20.7 & 21.2 & 21.8 & 23.4 & 24.5 & 25.1 & 24.6 & 25.4 & 25.6 & $26.0^{\neq}$ & 26.1 \\
\hline Israel & 9.9 & 14.7 & 16.1 & 16.8 & 16.7 & 16.6 & 17.3 & 17.5 & 17.4 & 17.7 & 17.3 & 16.5 \\
\hline Italy & 20.8 & 33.3 & 34.9 & 36.2 & 37.3 & 38.4 & 38.6 & 39.0 & 38.6 & 38.5 & 38.4 & - \\
\hline Korea & - & - & 33.6 & 36.9 & 36.7 & 36.7 & 36.3 & 35.1 & 35.3 & 35.4 & 35.1 & 35.2 \\
\hline Luxembourg & - & 21.9 & 24.3 & 25.6 & 26.1 & 26.8 & 27.2 & 27.1 & 29.0 & 30.1 & 29.3 & 29.3 \\
\hline Mexico & - & 28.2 & 30.4 & 33.2 & 34.7 & 37.0 & 38.2 & 39.5 & 40.7 & 43.9 & 42.0 & 44.8 \\
\hline Netherlands & 7.5 & 11.9 & 13.6 & 13.5 & 13.5 & 13.6 & 13.6 & 13.8 & 13.9 & 14.3 & 14.8 & - \\
\hline New Zealand & - & 20.2 & 21.2 & 22.2 & 22.2 & 22.3 & 22.7 & 23.9 & 22.8 & 22.8 & 24.0 & 23.5 \\
\hline Norway & 12.7 & 13.7 & 15.6 & 16.1 & 15.6 & 15.2 & 15.9 & 15.9 & 17.2 & 17.1 & 16.8 & - \\
\hline Poland & - & - & - & - & 15.7 & 16.4 & 18.5 & 19.5 & 19.0 & 19.3 & 22.8 & 26.0 \\
\hline Portugal & 18.6 & 23.9 & 25.4 & 25.7 & 26.6 & 27.0 & 27.8 & 31.0 & 31.2 & 32.7 & 33.0 & - \\
\hline Slovak Republic & 8.7 & 14.7 & 16.6 & 17.8 & 18.5 & 19.2 & 20.7 & 21.9 & 23.5 & 24.7 & 27.0 & - \\
\hline Slovenia & 8.6 & 11.0 & 12.5 & 13.7 & 14.4 & 14.3 & 15.5 & 16.4 & 16.8 & 17.0 & 17.8 & 19.1 \\
\hline Spain & 14.2 & 21.4 & 22.2 & 23.2 & 23.6 & 24.0 & 24.8 & 25.6 & 25.0 & 24.6 & $24.9^{\neq}$ & 25.5 \\
\hline Sweden & 10.4 & 14.5 & 15.6 & 16.1 & 16.5 & 16.7 & 17.1 & 17.6 & 17.7 & 17.0 & 17.5 & 16.8 \\
\hline Switzerland & 18.6 & - & - & 24.2 & 25.1 & 25.7 & 26.7 & 28.8 & 30.0 & 31.6 & 32.4 & 32.8 \\
\hline Turkey & - & - & - & - & - & - & - & 29.7 & 36.0 & 37.7 & 42.7 & - \\
\hline United Kingdom & 11.3 & 22.1 & 22.6 & 23.1 & 22.5 & 22.7 & 23.6 & 23.2 & 23.7 & 23.4 & 23.9 & 24.0 \\
\hline United States & 22.7 & 22.9 & 24.4 & 26.1 & 27.5 & 29.1 & 30.3 & 31.1 & 31.8 & 32.3 & 32.9 & - \\
\hline
\end{tabular}


Table 2: Characteristics of studies reporting economic costs by mode of delivery; studies including a caesarean section comparator published since 2000

\begin{tabular}{|c|c|c|c|c|c|c|c|c|c|c|c|}
\hline Study & $\begin{array}{l}\text { Date of } \\
\text { cohort }\end{array}$ & Location & $\begin{array}{l}\text { Type of } \\
\text { study }\end{array}$ & Currency & $\begin{array}{l}\text { Price } \\
\text { date }\end{array}$ & $\begin{array}{l}\text { Comparison } \\
\text { groups }\end{array}$ & $\begin{array}{l}\text { Type of } \\
\text { costs }\end{array}$ & $\begin{array}{l}\text { Cost vs } \\
\text { charges }\end{array}$ & $\begin{array}{l}\text { Time } \\
\text { horizon }\end{array}$ & Data sources & Quality\# \\
\hline $\begin{array}{l}\text { Allen et al. } \\
{[20,21]}\end{array}$ & 1985-2002 & Canada & $\begin{array}{l}\text { Retrospective } \\
\text { cohort }\end{array}$ & US\$ & 2004 & $\begin{array}{l}\text { VD }(n=16,690) ; \\
\text { AVD }(n=5,846) ; \\
\text { CS labour } \\
(n=4,218) ; C S \\
\text { elective }(n=859)\end{array}$ & $\begin{array}{l}\text { Direct } \\
\text { medical } \\
\text { (excluded } \\
\text { overheads) }\end{array}$ & Costs & $\begin{array}{l}\text { Until } \\
\text { discharge }\end{array}$ & $\begin{array}{l}\text { Administrative } \\
\text { database }\end{array}$ & $\begin{array}{l}12 / 12 \\
12 / 12\end{array}$ \\
\hline Bost [22] & $2000-2001$ & $\begin{array}{l}\text { USA } \\
\text { (Texas) }\end{array}$ & $\begin{array}{l}\text { Retrospective } \\
\text { cohort }\end{array}$ & US\$ & $\begin{array}{l}\text { Not } \\
\text { specified }\end{array}$ & $\begin{array}{l}\text { VD; } \\
\text { Attempted } \\
\text { vaginal } \\
\text { delivery; } \\
\text { Elective CS } \\
\text { by parity } \\
\text { (nulliparous vs } \\
\text { multiparous) }\end{array}$ & $\begin{array}{l}\text { Direct } \\
\text { medical } \\
\text { (excluded } \\
\text { overheads, } \\
\text { MD, } \\
\text { NICU) }\end{array}$ & Costs & $\begin{array}{l}\text { Until } \\
\text { discharge }\end{array}$ & $\begin{array}{l}\text { Financial } \\
\text { database }\end{array}$ & $9 / 12$ \\
\hline $\begin{array}{l}\text { Clark et al. } \\
\text { [23] }\end{array}$ & $\begin{array}{l}\text { Not } \\
\text { applicable }\end{array}$ & USA & $\begin{array}{l}\text { Decision } \\
\text { analysis }\end{array}$ & US\$ & $\begin{array}{l}\text { Not } \\
\text { specified }\end{array}$ & $\begin{array}{l}\text { Repeat elective } \\
\text { CS; } \\
\text { Planned TOL } \\
\text { after CS }\end{array}$ & $\begin{array}{l}\text { Direct } \\
\text { medical } \\
\text { (excluded } \\
\text { MD) }\end{array}$ & Costs & $\begin{array}{l}\text { Long-run } \\
\text { (not } \\
\text { specified) }\end{array}$ & $\begin{array}{l}\text { Hospital } \\
\text { financial } \\
\text { database }\end{array}$ & $9 / 12$ \\
\hline $\begin{array}{l}\text { Comas et al. } \\
\text { [24] }\end{array}$ & 2006-2007 & $\begin{array}{l}\text { Spain } \\
\text { (Barcelona) }\end{array}$ & $\begin{array}{l}\text { Cross- } \\
\text { sectional } \\
\text { study }\end{array}$ & Euro $€$ & $\begin{array}{l}\text { Not } \\
\text { specified }\end{array}$ & $\begin{array}{l}\text { Spontaneous } \\
\text { VD }(n=575) ; \\
\text { Instrumental } \\
\text { VD }(n=171) ; \\
\text { CS }(n=280)\end{array}$ & $\begin{array}{l}\text { Direct } \\
\text { medical } \\
\text { (hospital) }\end{array}$ & Costs & $\begin{array}{l}9 \text { months } \\
\text { pre-birth to } \\
3 \text { months } \\
\text { post-partum }\end{array}$ & $\begin{array}{l}\text { Hospital cost } \\
\text { accounting } \\
\text { system }\end{array}$ & $11 / 12$ \\
\hline $\begin{array}{l}\text { Declercq et } \\
\text { al. [25] }\end{array}$ & 1998-2003 & USA & $\begin{array}{l}\text { Retrospective } \\
\text { cohort }\end{array}$ & US\$ & $\begin{array}{l}\text { Inflated } \\
\text { to } 2003\end{array}$ & $\begin{array}{l}\text { Planned VD } \\
(n=240,754) ; \\
\text { Planned CS } \\
(n=3,334)\end{array}$ & Hospital & $\begin{array}{l}\text { Charges } \\
\text { (hospital- } \\
\text { specific) }\end{array}$ & $\begin{array}{l}\text { Until } 12 \\
\text { months } \\
\text { postpartum }\end{array}$ & $\begin{array}{l}\text { State-level } \\
\text { linked vital } \\
\text { statistics and } \\
\text { discharge } \\
\text { records }\end{array}$ & $9 / 12$ \\
\hline $\begin{array}{l}\text { Dimaio et } \\
\text { al. [26] }\end{array}$ & 1999 & $\begin{array}{l}\text { USA } \\
\text { (Florida) }\end{array}$ & $\begin{array}{l}\text { Retrospective } \\
\text { cohort }\end{array}$ & US\$ & $\begin{array}{l}\text { Not } \\
\text { specified }\end{array}$ & $\begin{array}{l}\text { Repeat elective } \\
\text { CS (n=65); } \\
\text { Planned TOL } \\
\text { after CS } \\
(n=139)\end{array}$ & $\begin{array}{l}\text { Direct } \\
\text { medical } \\
\text { (excluded } \\
\text { MD) }\end{array}$ & Costs & $\begin{array}{l}\text { Until } \\
\text { discharge }\end{array}$ & $\begin{array}{l}\text { Medical } \\
\text { records; } \\
\text { financial } \\
\text { database }\end{array}$ & $11 / 12$ \\
\hline Heer et al. & 2003 & Germany & Retrospective & Euro€ & Not & VD $(n=70)$ & Hospital & Costs & Until & Medical & $10 / 12$ \\
\hline
\end{tabular}




\begin{tabular}{|c|c|c|c|c|c|c|c|c|c|c|c|}
\hline [27] & & (Munich) & cohort & & specified & $\begin{array}{l}\text { Planned CS } \\
(n=30)\end{array}$ & & $\begin{array}{l}\text { returns } \\
\text { (insurance) }\end{array}$ & discharge & $\begin{array}{l}\text { records; } \\
\text { hospital } \\
\text { database }\end{array}$ & \\
\hline $\begin{array}{l}\text { James et al. } \\
\text { [28] }\end{array}$ & $1995-1997$ & UK & $\begin{array}{l}\text { Decision } \\
\text { analysis }\end{array}$ & GBPE & 1997 & $\begin{array}{l}\text { ECV for un- } \\
\text { complicated } \\
\text { breech } \\
\text { pregnancy; } \\
\text { assisted breech } \\
\text { delivery; } \\
\text { elective CS }\end{array}$ & Hospital & Costs & $\begin{array}{l}\text { Up to the } \\
\text { point of } \\
\text { delivery }\end{array}$ & $\begin{array}{l}\text { Hospital } \\
\text { records }\end{array}$ & $12 / 12$ \\
\hline $\begin{array}{l}\text { Kamath et } \\
\text { al. [29] }\end{array}$ & $2005-2008$ & $\begin{array}{l}\text { USA } \\
\text { (Denver) }\end{array}$ & $\begin{array}{l}\text { Retrospective } \\
\text { cohort }\end{array}$ & US\$ & 2008 & $\begin{array}{l}\text { Repeat elective } \\
\text { CS without } \\
\text { labour (n=239); } \\
\text { Repeat elective } \\
\text { CS with labour } \\
(\mathrm{n}=104) ; \\
\text { VBAC (n=244); } \\
\text { Failed VBAC } \\
(\mathrm{n}=85)\end{array}$ & Hospital & Costs & $\begin{array}{l}\text { Until } \\
\text { discharge }\end{array}$ & $\begin{array}{l}\text { Medical } \\
\text { invoices; } \\
\text { hospital } \\
\text { records }\end{array}$ & $10 / 12$ \\
\hline $\begin{array}{l}\text { Kazandjian } \\
\text { et al. [30] }\end{array}$ & 2004 & $\begin{array}{l}\text { USA } \\
\text { (Maryland) }\end{array}$ & $\begin{array}{l}\text { Retrospective } \\
\text { cohort }\end{array}$ & US\$ & $\begin{array}{l}\text { Not } \\
\text { specified }\end{array}$ & $\begin{array}{l}\text { VD }(n=141) ; \\
\text { CS }(n=186)\end{array}$ & $\begin{array}{l}\text { Direct } \\
\text { medical }\end{array}$ & Charges & $\begin{array}{l}\text { Until } \\
\text { discharge }\end{array}$ & Hospital charts & $9 / 12$ \\
\hline $\begin{array}{l}\text { Khan and } \\
\text { Zaman [31] }\end{array}$ & 2008 & $\begin{array}{l}\text { Pakistan } \\
\text { (Islamabad) }\end{array}$ & $\begin{array}{l}\text { Retrospective } \\
\text { cohort }\end{array}$ & US\$ & 2008 & $\begin{array}{l}\text { SVD }(n=68) ; \\
\operatorname{CS}(n=65)\end{array}$ & $\begin{array}{l}\text { Hospital, } \\
\text { Household }\end{array}$ & Costs & $\begin{array}{l}\text { Until } \\
\text { discharge }\end{array}$ & $\begin{array}{l}\text { Hospital } \\
\text { records; } \\
\text { accounts; } \\
\text { interviews }\end{array}$ & $12 / 12$ \\
\hline $\begin{array}{l}\text { Palencia et } \\
\text { al. [32] }\end{array}$ & $\begin{array}{l}1997- \\
2000\end{array}$ & Multinational & RCT & CAN\$ & 2002 & $\begin{array}{l}\text { Planned VD } \\
(n=511) \text { or CS } \\
(n=514) \text { for } \\
\text { breech } \\
\text { presentation }\end{array}$ & $\begin{array}{l}\text { Direct } \\
\text { medical }\end{array}$ & Costs & $\begin{array}{l}\text { Until } 6 \\
\text { weeks } \\
\text { postpartum }\end{array}$ & RCT data & $12 / 12$ \\
\hline $\begin{array}{l}\text { Petrou and } \\
\text { Glazener } \\
\text { [33] }\end{array}$ & 1990-1991 & Scotland & $\begin{array}{l}\text { Retrospective } \\
\text { cohort }\end{array}$ & GBE & $\begin{array}{l}1999- \\
2000\end{array}$ & $\begin{array}{l}\text { SVD }(n=894) ; \\
\text { Instrumental } \\
\text { VD ( } n=168) ; \\
\text { CS }(n=180)\end{array}$ & $\begin{array}{l}\text { Hospital } \\
\text { and } \\
\text { community } \\
\text { health } \\
\text { services }\end{array}$ & Costs & $\begin{array}{l}\text { Until } 2 \\
\text { months } \\
\text { postpartum }\end{array}$ & $\begin{array}{l}\text { Medical case } \\
\text { notes; } \\
\text { computerised } \\
\text { hospital } \\
\text { discharge } \\
\text { records; self- } \\
\text { completed } \\
\text { questionnaires } \\
\end{array}$ & $12 / 12$ \\
\hline $\begin{array}{l}\text { Sarowar et } \\
\text { al. [34] }\end{array}$ & $2006-2007$ & $\begin{array}{l}\text { Bangladesh } \\
\text { (Dhaka) }\end{array}$ & $\begin{array}{l}\text { Retrospective } \\
\text { cohort }\end{array}$ & US\$ & 2006 & $\begin{array}{l}\text { Normal } \\
\text { Delivery } \\
(n=11) ; \\
\end{array}$ & Hospital & Costs & $\begin{array}{l}\text { Until } 6 \\
\text { weeks } \\
\text { postpartum } \\
\end{array}$ & $\begin{array}{l}\text { Hospital } \\
\text { records }\end{array}$ & $12 / 12$ \\
\hline
\end{tabular}


Abbreviations: AVD, assisted vaginal delivery; CS, Caesarean section; ECV, external cephalic version; MD, medical doctor; NICU, neonatal intensive care unit; RCT, randomised control trial; SVD, spontaneous vaginal delivery; TOL, trial of labour; VBAC, vaginal birth after caesarean; VD, Vaginal delivery.

\# Study quality assessed using 12 relevant criteria (items 1, 2, 3, 4, 5, 6, 7, 8, 9, 13, 14, 22) extracted from the CHEERS reporting checklist. ${ }^{[35]}$ 
Table 3: Characteristics of economic evaluations; studies including a caesarean section comparator published since 2000

\begin{tabular}{|c|c|c|c|c|c|c|c|c|c|c|c|}
\hline Study & Location & $\begin{array}{l}\text { Type of } \\
\text { study }\end{array}$ & Sample size & Currency & $\begin{array}{l}\text { Price } \\
\text { date }\end{array}$ & $\begin{array}{l}\text { Comparison } \\
\text { groups }\end{array}$ & $\begin{array}{l}\text { Type of } \\
\text { costs }\end{array}$ & $\begin{array}{l}\text { Cost } \\
\text { versus } \\
\text { charges }\end{array}$ & $\begin{array}{l}\text { Time } \\
\text { horizon }\end{array}$ & Data sources & Quality\# \\
\hline $\begin{array}{l}\text { Chen et al. } \\
\text { [39] }\end{array}$ & USA & $\begin{array}{l}\text { Decision } \\
\text { analytic } \\
\text { model }\end{array}$ & $\begin{array}{l}\text { Hypothetical } \\
\text { cohort of } 7000 \\
\text { women }\end{array}$ & US\$ & 1998 & $\begin{array}{l}\text { Elective CS versus } \\
\text { usual care in HIV- } \\
\text { infected women }\end{array}$ & $\begin{array}{l}\text { Medical } \\
\text { system; } \\
\text { Third party } \\
\text { payers }\end{array}$ & Costs & Lifetime & $\begin{array}{l}\text { Published } \\
\text { literature; } \\
\text { National } \\
\text { databases }\end{array}$ & $21 / 24$ \\
\hline $\begin{array}{l}\text { Chung et al. } \\
\text { [40] }\end{array}$ & $\begin{array}{l}\text { USA } \\
\text { (Stanford) }\end{array}$ & $\begin{array}{l}\text { Decision } \\
\text { analytic } \\
\text { model }\end{array}$ & $\begin{array}{l}\text { Based on } \\
\text { hypothetical } \\
\text { 30-year old } \\
\text { parturient } \\
\end{array}$ & US\$ & 2000 & $\begin{array}{l}\text { Elective CS } \\
\text { versus planned } \\
\text { TOL after CS }\end{array}$ & $\begin{array}{l}\text { Societal; } \\
\text { Medical }\end{array}$ & Costs & Lifetime & Financial database & $17 / 24$ \\
\hline $\begin{array}{l}\text { Culligan et } \\
\text { al. [41] }\end{array}$ & USA & $\begin{array}{l}\text { Decision } \\
\text { analytic } \\
\text { model }\end{array}$ & $\begin{array}{l}\text { Hypothetical } \\
\text { cohort of } \\
100,000 \\
\text { deliveries }\end{array}$ & US\$ & $\begin{array}{l}\text { Not } \\
\text { reported }\end{array}$ & $\begin{array}{l}\text { Spontaneous labour } \\
\text { followed by either } \\
\text { vaginal delivery or } \\
\text { CS versus } \\
\text { ultrasound followed } \\
\text { by elective CS in } \\
\text { cases of } \\
\text { macrosomia } \\
\end{array}$ & Societal & Costs & Lifetime & $\begin{array}{l}\text { Published } \\
\text { literature; } \\
\text { Expert opinion }\end{array}$ & $22 / 24$ \\
\hline $\begin{array}{l}\text { Fawsitt et } \\
\text { al. [42] }\end{array}$ & Ireland & $\begin{array}{l}\text { Decision } \\
\text { analytic } \\
\text { model }\end{array}$ & $\begin{array}{l}\text { Hypothetical } \\
\text { cohort of } \\
10000 \text { women }\end{array}$ & Euro€ & 2010 & $\begin{array}{l}\text { ERCD } \\
\text { versus planned } \\
\text { TOL after CS }\end{array}$ & $\begin{array}{l}\text { Direct } \\
\text { medical }\end{array}$ & Costs & Six weeks & $\begin{array}{l}\text { Resource use } \\
\text { inventory; } \\
\text { Hospital database; } \\
\text { Published } \\
\text { literature }\end{array}$ & $22 / 24$ \\
\hline $\begin{array}{l}\text { Grobman et } \\
\text { al. [43] }\end{array}$ & USA & $\begin{array}{l}\text { Decision } \\
\text { analytic } \\
\text { model }\end{array}$ & $\begin{array}{l}\text { Hypothetical } \\
\text { cohort of } \\
100,000 \\
\text { women } \\
\end{array}$ & US\$ & 1999 & $\begin{array}{l}\text { Elective CS } \\
\text { versus planned } \\
\text { TOL after CS }\end{array}$ & $\begin{array}{l}\text { Medical } \\
\text { system; } \\
\text { Third party } \\
\text { payers }\end{array}$ & Costs & $\begin{array}{l}\text { Completion } \\
\text { of } \\
\text { reproductive } \\
\text { lives }\end{array}$ & $\begin{array}{l}\text { Published } \\
\text { literature; } \\
\text { Expert opinion }\end{array}$ & $22 / 24$ \\
\hline $\begin{array}{l}\text { Halpern et } \\
\text { al. [44] }\end{array}$ & USA & $\begin{array}{l}\text { Decision } \\
\text { analytic } \\
\text { model }\end{array}$ & $\begin{array}{l}4958 \text { HIV- } \\
\text { infected } \\
\text { women } \\
\text { delivering } \\
\text { annually }\end{array}$ & US\$ & 1998 & $\begin{array}{l}\text { Elective CS versus } \\
\text { VD by } \\
\text { antiretroviral } \\
\text { therapy regimen }\end{array}$ & $\begin{array}{l}\text { Direct } \\
\text { medical }\end{array}$ & Costs & Lifetime & $\begin{array}{l}\text { Published } \\
\text { literature }\end{array}$ & $20 / 24$ \\
\hline
\end{tabular}




\begin{tabular}{|c|c|c|c|c|c|c|c|c|c|c|c|}
\hline Herbst [45] & USA & $\begin{array}{l}\text { Decision } \\
\text { analytic } \\
\text { model }\end{array}$ & $\begin{array}{l}100 \text { pregnant } \\
\text { women }\end{array}$ & US\$ & $\begin{array}{l}\text { Not } \\
\text { reported }\end{array}$ & $\begin{array}{l}\text { Elective CS versus } \\
\text { induction of labour } \\
\text { versus } \\
\text { expectant } \\
\text { management for } \\
\text { macrosomia }\end{array}$ & $\begin{array}{l}\text { Direct } \\
\text { medical }\end{array}$ & $\begin{array}{l}\text { Reimb- } \\
\text { ursement } \\
\text { costs }\end{array}$ & $\begin{array}{l}\text { Not } \\
\text { specified }\end{array}$ & $\begin{array}{l}\text { Published } \\
\text { literature }\end{array}$ & $17 / 24$ \\
\hline $\begin{array}{l}\text { Mrus et al. } \\
\text { [46] }\end{array}$ & USA & $\begin{array}{l}\text { Decision } \\
\text { analytic } \\
\text { model }\end{array}$ & Not applicable & US\$ & 1997 & $\begin{array}{l}\text { Elective CS versus } \\
\text { VD in HIV- } \\
\text { infected women }\end{array}$ & Societal & $\begin{array}{l}\text { Costs; } \\
\text { Charges }\end{array}$ & Lifetime & $\begin{array}{l}\text { Published } \\
\text { literature }\end{array}$ & $22 / 24$ \\
\hline $\begin{array}{l}\text { NICE } \\
\text { Guideline } \\
\text { [2] }\end{array}$ & UK & $\begin{array}{l}\text { Decision } \\
\text { analytic } \\
\text { model }\end{array}$ & Not applicable & GBE & $2009 / 10$ & $\begin{array}{l}\text { Planned VD versus } \\
\text { planned CDMR }\end{array}$ & $\begin{array}{l}\text { NHS and } \\
\text { personal } \\
\text { social } \\
\text { services }\end{array}$ & Costs & $\begin{array}{l}\text { Until } \\
\text { discharge } \\
\text { (costs); } \\
\text { Lifetime } \\
\text { (QALYs) }\end{array}$ & $\begin{array}{l}\text { Published } \\
\text { literature }\end{array}$ & $22 / 24$ \\
\hline $\begin{array}{l}\text { Plunkett et } \\
\text { al. [47] }\end{array}$ & USA & $\begin{array}{l}\text { Decision } \\
\text { analytic } \\
\text { model }\end{array}$ & Not applicable & US\$ & 2001 & $\begin{array}{l}\text { Elective CS versus } \\
\text { CS only for } \\
\text { obstetric indications } \\
\text { to prevent perinatal } \\
\text { HCV transmission }\end{array}$ & $\begin{array}{l}\text { Direct } \\
\text { medical }\end{array}$ & Costs & Lifetime & $\begin{array}{l}\text { Published } \\
\text { literature }\end{array}$ & $22 / 24$ \\
\hline $\begin{array}{l}\text { Schakman } \\
\text { et al. [48] }\end{array}$ & USA & $\begin{array}{l}\text { Decision } \\
\text { analytic } \\
\text { model }\end{array}$ & Not applicable & US\$ & 2003 & $\begin{array}{l}\text { Elective CS versus } \\
\text { CS only for } \\
\text { obstetric indications } \\
\text { to prevent perinatal } \\
\text { HCV transmission }\end{array}$ & Societal & Costs & Lifetime & $\begin{array}{l}\text { Published } \\
\text { literature; } \\
\text { National } \\
\text { databases }\end{array}$ & $23 / 24$ \\
\hline
\end{tabular}

Abbreviations: CDMR, caesarean delivery on maternal request; CS, caesarean section; ERCD, elective repeat caesarean delivery; HCV, hepatitis C virus;

TOL, trial of labour; TOLAC, trial of labour after caesarean; VD, vaginal delivery.

\# Study quality assessed using all 24 criteria extracted from the CHEERS reporting checklist. ${ }^{[35]}$ 


\section{Appendix 1: Search strategy}

Research studies on the costs and cost-effectiveness of aspects of elective caesarean section were identified by searches of the following electronic bibliographic databases: PubMed, MEDLINE, EMBASE, CINAHL, The Cochrane Library (CDSR), Web of Knowledge and Google Scholar.

In order for the analyses to be considered appropriate to the modern context, studies were excluded from the literature search if they were published before 2000. Studies were also excluded if the abstract was not published in English language or if the focus was animal research. The MESH terms used in all searches were:

“Caesarean section” or “Cesarean section” or “Cesarean section” or “C section” or "Laparotomy” or "Hysterotomy" - [All Fields] and [MeSH Terms]

Combined with:

"Economics" or "Economic" or "Cost" or "Financial" or “cost-effectiveness”- [All Fields] and [MeSH Terms],“Burden” - [All Fields] 
Appendix 2: Results of studies reporting economic costs by mode of delivery; studies including a caesarean section comparator published since 2000

\begin{tabular}{|c|c|c|c|}
\hline Study & Date of cohort & Location & Results \\
\hline $\begin{array}{l}\text { Allen et al. [20] } \\
\text { Allen et al. [21] }\end{array}$ & $1985-2002$ & Canada & $\begin{array}{l}\text { (i) Mean cost (SD): } \\
\text { VD: } \$ 1,340 \text { (1058); AVD: } \$ 1,594(1387) \text {; } \\
\text { CS labour: } \$ 2,137 \text { (2252); CS elective: } \$ 1,532(1214) \\
\text { (ii) Cumulative mean (range) cost through to third delivery by first delivery type: } \\
\text { VD: } \$ 6,425(3,170-107,215) \text {; AVD: } \$ 7,288(3688-190,902) \text {; } \\
\text { CS labour: } \$ 9,524(4801-57642) \text {; CS elective: } \$ 7,213(4539-16560) \\
\end{array}$ \\
\hline Bost [22] & $2000-2001$ & $\begin{array}{l}\text { USA } \\
\text { (Texas) }\end{array}$ & $\begin{array}{l}\text { Mean cost: } \\
\text { Nulliparous } \\
\text { VD: \$779; Attempted vaginal delivery: \$972; CS elective: \$918 } \\
\text { Multiparous } \\
\text { VD: \$734; Attempted vaginal delivery: \$853; CS elective: \$918 }\end{array}$ \\
\hline Clark et al. [23] & Not applicable & USA & $\begin{array}{l}\text { Cost per mode of delivery after previous CS: } \\
\text { VBAC success rate } 70 \% \text { : Planned TOL: } \$ 2,611 \text {; Elective CS: } \$ 3,042 \\
\text { VBAC success rate } 60 \% \text { : Planned TOL: } \$ 2,762 ; \text { Elective CS: } \$ 3,042 \\
\text { VBAC success rate 50\%: Planned TOL } \$ 2,915 ; \text { Elective CS: } \$ 3,042\end{array}$ \\
\hline Comas et al. [24] & $2006-2007$ & Spain (Barcelona) & $\begin{array}{l}\text { Mean (SD) total cost per delivery: } \\
\text { Spontaneous vaginal delivery: } € 3,682(1,748) \\
\text { Instrumental vaginal delivery: } € 4,064(1,222) \\
\text { CS: } € 5,815(3,232)\end{array}$ \\
\hline Declercq et al. [25] & $1998-2003$ & USA & $\begin{array}{l}\text { Initial hospital stay: } \\
\text { Mean cost (95\% CI): Planned VD \$2,513 (2,507-2,519); Planned CS \$4,373 }(4,304-4,441) \\
\text { Mean length of stay (days) (95\% CI): Planned VD } 2.4 \text { (2.43-2.44); Planned CS 4.3 }(4.27-4.35) \\
\text { Subsequent rehospitalisation: } \\
\text { Mean cost (95\% CI): Planned VD \$5,436 (5,221-5,651); Planned CS \$6,100 }(4,745-7,455) \\
\text { Mean length of stay (days) (95\% CI): Planned VD } 3.9 \text { (3.75-4.04); Planned CS 4.3 (3.56-5.12) }\end{array}$ \\
\hline Dimaio et al. [26] & 1999 & USA (Florida) & $\begin{array}{l}\text { Mean hospital cost (SD) per mode of delivery after previous CS: } \\
\text { Elective repeat CS: mother-infant dyad } \$ 5,949 \text { (2365), mothers } \$ 4,155 \text { (661), infants } \$ 1,794 \text { (2122) } \\
\text { TOL: mother-infant dyad } \$ 4,863(2151) \text {, mothers } \$ 3,675 \text { (936), infants } \$ 1,187(1761) \\
\text { Successful TOL: } \$ 4,411 \text {, Failed TOL: } \$ 6,272\end{array}$ \\
\hline Heer et al. [27] & 2003 & Germany (Munich) & $\begin{array}{l}\text { Mean total cost: } \\
\text { VD: €1,737; Planned CS: €2,835 }\end{array}$ \\
\hline James et al. [28] & $1995-1997$ & UK & $\begin{array}{l}\text { The mean additional costs for ECV, assisted breech delivery and elective caesarean over and above a normal birth } \\
\text { were } £ 186.70, £ 425.36 \text { and } £ 1,955.22 \text {, respectively }\end{array}$ \\
\hline
\end{tabular}




\begin{tabular}{|c|c|c|c|}
\hline & & & $\begin{array}{l}\text { The total expected cost of the respective care pathways for "ECV accepted" and "ECV not accepted" (including the } \\
\text { probability of adverse events) were } £ 1,452 \text { and } £ 1,828 \text { respectively. }\end{array}$ \\
\hline Kamath et al. [29] & $2005-2008$ & USA (Denver) & $\begin{array}{l}\text { Mean cost }(95 \% \text { CI): } \\
\text { Elective repeat CS without labour: mother } \$ 6,030(\$ 4,543, \$ 8,572) \text {; neonate } \$ 2,094(\$ 1,400, \$ 4,742) \text {; total } \$ 8,239 \\
(\$ 6,212, \$ 13,968) \\
\text { Elective repeat CS with labour: mother } \$ 6,073(\$ 4,319, \$ 8,745) \text {; neonate } \$ 2,103(\$ 1,414, \$ 4,007) ; \text { total } \$ 8,331 \\
(\$ 5,995, \$ 11,310) \\
\text { VBAC: } \text { Fother } \$ 4,345(\$ 2,761, \$ 7,374) ; \text { neonate } \$ 1,453(\$ 797, \$ 3,067) ; \text { total } \$ 5,853(\$ 3,793, \$ 10,333) \\
\text { Failed VBAC: mother } \$ 7,292(\$ 5,295, \$ 11,162) ; \text { neonate } \$ 2,129(\$ 1,336, \$ 5,470) ; \text { total } \$ 9,338(\$ 6,631, \$ 16,275)\end{array}$ \\
\hline Kazandjian et al. [30] & 2004 & USA (Maryland) & $\begin{array}{l}\text { Mean cost: } \\
\text { VD } \$ 17,624 ; \text { CS } \$ 13,805\end{array}$ \\
\hline Khan and Zaman [31] & 2008 & $\begin{array}{l}\text { Pakistan } \\
\text { (Islamabad) }\end{array}$ & $\begin{array}{l}\text { Mean cost: } \\
\text { SVD: Hospital perspective US\$40; patient perspective US\$79 } \\
\text { CS: Hospital perspective US\$162; patient perspective US\$204 }\end{array}$ \\
\hline Palencia et al. [32] & $1997-2000$ & Multinational & $\begin{array}{l}\text { Mean cost (SE): } \\
\text { (i) All women (breech presentation): planned CS: \$7,165 (110); planned VD: \$8,042 (175); mean cost difference } \\
\text { (95\% credible interval: }-877 \text { (-1286 to -473) } \\
\text { (ii) First birth (breech presentation): planned CS: \$7,255 (121); planned VD: \$8,440 (208; mean cost difference } \\
\text { (95\% credible interval: }-1185 \text { (-1663 to -719) } \\
\text { (iii) At least one prior birth (breech presentation): planned CS: \$7,071 (188); planned VD: \$7,559 (284); mean } \\
\text { cost difference (95\% credible interval: -488 (-1163 to 166) }\end{array}$ \\
\hline $\begin{array}{l}\text { Petrou and Glazener } \\
\text { [33] }\end{array}$ & 1990-1991 & Scotland & $\begin{array}{l}\text { (i) Initial Hospital stay: } \\
\text { Mean cost (95\% CI): SVD } £ 1431.3 \text { (1410.7- 1451.9); instrumental VD £1969.7 (1918.4- 2020.9); CS £2923.5 } \\
\text { (2880.1-2966.9) } \\
\text { Mean LOS (SD): SVD 4.4 (1.8); instrumental VD 5.8(1.9); CS 7.1(1.8) } \\
\text { (ii) Subsequent rehospitalisation: } \\
\text { Mean cost (95\% CI): SVD £1697.7 (1674.4- 1720.9); instrumental VD £ } 2262.0 \text { (2203.6- 2320.4); CS £ } 3200.2 \\
\text { (3147.7-3252.8) } \\
\text { Mean LOS (SD): SVD } 14 \text { (1.6); instrumental VD 3(1.8); CS } 3 \text { (1.7) }\end{array}$ \\
\hline Sarowar et al. [34] & $2006-2007$ & $\begin{array}{l}\text { Bangladesh } \\
\text { (Dhaka) }\end{array}$ & $\begin{array}{l}\text { Mean cost for } 6 \text { weeks care post birth: } \\
\text { Caesarean section: without complication } \$ 89.98 \text {; with complication } \$ 117.12 \\
\text { Normal Delivery: without complication } \$ 43.63 \text {; with complication } \$ 112.46\end{array}$ \\
\hline
\end{tabular}

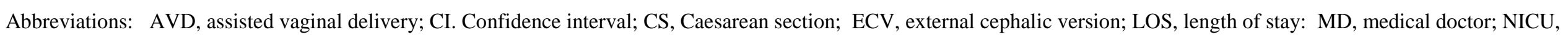

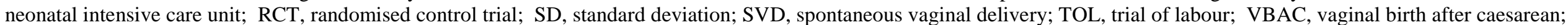
VD, Vaginal delivery. 


\section{Appendix 3: Results of economic evaluations; studies including a caesarean section comparator published since 2000}

\begin{tabular}{|c|c|c|c|c|}
\hline Study & Location & Cost components & Cost-effectiveness results & Sensitivity analyses \\
\hline Chen et al. [39] & USA & $\begin{array}{l}\text { VD no complications: } \$ 2,269 \\
\text { VD with complications: } \$ 3,230 \\
\text { CS no complications: } \$ 4,316 \\
\text { CS with complications: } \$ 5,576\end{array}$ & $\begin{array}{l}\text { Base case ICER was } \$ 37,284 \text { per case of perinatal } \\
\text { transmission prevented with the elective CS } \\
\text { delivery strategy. }\end{array}$ & $\begin{array}{l}\text { The elective CS delivery strategy remained cost- } \\
\text { effective during the univariate sensitivity analyses. }\end{array}$ \\
\hline Chung et al. [40] & USA & $\begin{array}{l}\text { Mean hospital cost (range) per mode of } \\
\text { delivery after previous CS: } \\
\text { Successful TOL: } \$ 4,950(\$ 3,900-\$ 6,000) \\
\text { Failed TOL: } \$ 8,414(\$ 7,000-\$ 10,000) \\
\text { Elective repeat CS: } \$ 7,244(\$ 5,900-\$ 8,600)\end{array}$ & $\begin{array}{l}\text { Base case ICER for elective repeat CS over TOL } \\
\text { was } \$ 112,023 \text { per QALY gained. Assumed a } 75 \% \\
\text { probability of successful VBAC. }\end{array}$ & $\begin{array}{l}\text { If probability of successful VBAC }<0.65 \text {, elective } \\
\text { repeat CS was the dominant choice. } \\
\text { If probability was between } 0.65 \text { and } 0.74 \text { elective } \\
\text { repeat CS was the cost effective method. } \\
\text { TOL was cost-effective between the range of } 0.75 \\
\text { and } 0.76 \text { and dominant when the probability of } \\
\text { successful VBAC was greater than } 0.76 \text {. }\end{array}$ \\
\hline Culligan et al. [41] & USA & $\begin{array}{l}\text { Uncomplicated VD: } \$ 4,187 \\
\text { Complicated VD: } \$ 5,618 \\
\text { Uncomplicated elective CS: } \$ 7,361 \\
\text { Complicated elective CS: } \$ 10,364 \\
\text { Uncomplicated non-elective CS: } \$ 8,740 \\
\text { Complicated non-elective CS: } \$ 12,494\end{array}$ & $\begin{array}{l}\text { For every } 100,000 \text { deliveries, the standard care } \\
\text { policy cost } \$ 850,581,000 \text { and the elective CS policy } \\
\text { cost } \$ 847,370,000 \text {. New policy resulted in cost } \\
\text { saving of } \$ 3,211,000 \text { for every } 100,000 \text { deliveries. } \\
\text { Expected quality of life for mother/new-born dyad } \\
\text { was } 0.917 \text { for standard care and } 0.923 \text { for the } \\
\text { elective CS policy. Standard care approach resulted } \\
\text { in 53.2 QALYs and the elective CS policy resulted } \\
\text { in 53.6 QALYs. }\end{array}$ & $\begin{array}{l}\text { If the probability of urinary incontinence resulting } \\
\text { from a VD decreased from } 0.245 \text { to } 0.217 \text { or the } \\
\text { probability of urinary incontinence resulting from an } \\
\text { elective CS was raised from } 0.05 \text { to } 0.072 \text {, this } \\
\text { would result in monetary costs being equal for the } \\
\text { two programmes. } \\
\text { If the costs of urinary incontinence were lowered by } \\
13 \text { per cent, or if the cost of vaginal delivery were } \\
\text { lowered by } 10 \text { per cent, then the standard care } \\
\text { policy would be less costly. }\end{array}$ \\
\hline Fawsitt et al. [42] & Ireland & $\begin{array}{l}\text { Mean cost: } \\
\text { TOL: } € 1,830.73 \\
\text { ERCD: } € 4,039.87\end{array}$ & $\begin{array}{l}\text { The ICER for a TOL was dominant. } \\
\text { The probability that TOL was cost-effective was } \\
100 \text { per cent. }\end{array}$ & $\begin{array}{l}\text { A TOLAC was cost-effective if the probability of } \\
\text { success was } 67 \% \text {. Varying the success rate between } \\
64 \% \text { and } 69 \% \text { did not alter the cost-effectiveness } \\
\text { results. }\end{array}$ \\
\hline Grobman et al. [43] & USA & $\begin{array}{l}\text { VD after TOL: } \$ 3,578 \\
\text { Elective CS: } \$ 5,511 \\
\text { CS after TOL: } \$ 6,889\end{array}$ & $\begin{array}{l}\text { The prevention of one major adverse neonatal } \\
\text { outcome (death or cerebral palsy) requires } 1591 \mathrm{CS} \\
\text { deliveries and a cost of more than } \$ 2.4 \text { million. }\end{array}$ & $\begin{array}{l}\text { Sensitivity analysis confirmed the robustness of the } \\
\text { analyses. }\end{array}$ \\
\hline Halpern et al. [44] & USA & $\begin{array}{l}\text { VD without postpartum morbidity: } \$ 5,876 \\
\text { VD with postpartum morbidity: } \$ 9,319 \\
\text { CS without postpartum morbidity: } \$ 9,982 \\
\text { CS with postpartum morbidity: } \$ 11,654\end{array}$ & $\begin{array}{l}\text { No ART: } \\
\text { Elective CS results in both better outcomes and } \\
\text { decreased costs in comparison with VD. } \\
\text { Ziduvudine prophylaxis: } \\
\text { Additional cost per life year saved is } \$ 17 \text { and cost } \\
\text { per case avoided is } \$ 1,131 \\
\text { Combination ART: } \\
\text { Additional cost per life year saved is } \$ 1,697 \text { and } \\
\text { cost per case avoided is } \$ 112,693\end{array}$ & $\begin{array}{l}\text { Elective CS is less cost-effective (compared to VD) } \\
\text { when vertical transmission rates with VD are } \\
\text { already low, and more cost-effective when these } \\
\text { transmission rates are higher. } \\
\text { If the transmission rate with elective CS is higher } \\
\text { than in the base-case model, combination ART with } \\
\text { VD results in both decreased costs and better } \\
\text { outcomes. }\end{array}$ \\
\hline
\end{tabular}


Population based analyses indicated that elective

CS could prevent 239 paediatric HIV cases

annually with a saving of over $\$ 4$ million.

Herbst [45] USA $\quad$ Vaginal delivery: \$3,376

Elective CS: $\$ 5,200$

Expectant management was the preferred strategy at

Emergency CS: $\$ 6,500$

a cost of $\$ 4,014.33$ per injury-free child, compared

with elective CS at a cost of $\$ 5,212.06$ and

Expectant management is the preferred method if

induction at a cost of $\$ 5165.08$.

\begin{tabular}{lll}
\hline Mrus et al. [46] & US & Vaginal delivery: $\$ 2,930$ \\
& VD with complications: $\$ 3,809$ \\
& Elective CS: $\$ 4,102$
\end{tabular}

Elective CS: cost per birth $\$ 10,600$, QALYs 38.7

per mother and child pair.

Elective CS: \$4,102

VD: cost per birth \$15,500, QALYs 38.2 per

Emergency CS: \$4,395 mother and child pair.

\begin{tabular}{lll}
\hline NICE Guideline [2] & UK & Planned VD: $£ 1,954$ \\
& & Planned CS: £2,664
\end{tabular}

Plunkett et al. [47] USA

Elective CS: \$6,001

Emergency CS: \$7,502

Vaginal delivery: \$3,116

The ICER for planned VD was dominant with a probability of cost-effectiveness of $100 \%$ across cost-effectiveness thresholds.

Elective CS: cost \$45,814, QALYs 29.1821.

Standard care: cost \$44,653, QALYs 29.1487

ICER: \$34,812 per QALY gained.

the incidence of shoulder dystocia and permanent injury remain $<10 \%$.

Results were robust over a wide range of assumptions.

Only when the HIV transmission rate fell below $1.3 \%$ or the relative risk of transmission with elective CS exceeded 0.89 did the elective CS cost more than VD.

Planned vaginal birth versus planned CDMR: Planned vaginal birth dominated CDMR with a probability of cost-effectiveness of $100 \%$.

Elective CS would be cost-effective if perinatal $\mathrm{HCV}$ transmission rates were to reduce from 7.75 to $1.7 \%$ or less.

At a discount rate of $0 \%$ elective CS dominated standard care. When a 5\% discount rate was applied elective CS was no longer cost-effective.

\begin{tabular}{|c|c|c|}
\hline $\begin{array}{l}\text { Schackman et al. } \\
\text { [48] }\end{array}$ & USA & $\begin{array}{l}\text { Uncomplicated VD: } \$ 4,490 \\
\text { Complicated VD: } \$ 5,560 \\
\text { Uncomplicated CS: } \$ 6,946 \\
\text { Complicated CS: } \$ 8,553\end{array}$ \\
\hline
\end{tabular}

1) Probability of child developing chronic HCV infection was 50\%:

Results were sensitive to the efficacy of C-section in preventing transmission, the probability of vaginal

ICER for elective CS over standard care was \$6,100 delivery without a recommendation, and rates of per QALY gained

2) Probability of child developing chronic HCV maternal acceptance of the recommendation.

infection was $25 \%$ :

ICER for elective CS over standard care was $\$ 3,900$ per QALY gained

\begin{tabular}{lll}
\hline Xu et al. [49] & USA & Mean cost $(95 \%$ CI): \\
& TOL: $\$ 13,283(7,861-23,829)$ \\
& CDMR: $\$ 14,259(8,964-24,002)$
\end{tabular}

TOL: Mean cost \$13,283; Mean QALYs 57.87

CDMR: Mean cost \$14,259; Mean QALYs 58.21

Mean difference in costs (95\% CI): \$976 (-\$7,863

to $\$ 7,935$ )

Mean difference in QALYs (95\% CI): 0.35 (-0.24

to 1.10$)$

In $12.14 \%$ of the iterations, CDMR was dominated by TOL whereas in $33.32 \%$ of the iterations, CDMR was the dominant strategy. In the other $54.54 \%$ of the iterations, one delivery scheme was less costly and the other generated higher QALYs.

The probability of CDMR being cost-effective never exceeded $88 \%$ for any cut-off for the costeffectiveness ratio.

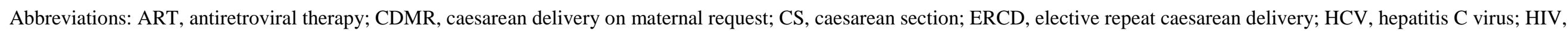

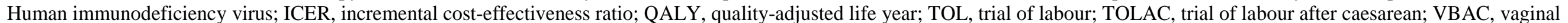


birth after caesarean; VD, vaginal delivery. 